\title{
Analiza kompetencji rodziców w zakresie bezpieczeństwa dzieci w Internecie
}

KEY WORDS

threats in the Internet, children's safety in the Internet, children in the Web, parents of children in the Web, Internet competences of parents, Internet competences of children

\begin{abstract}
Bartkowiak Anna, Analiza kompetencji rodziców w zakresie bezpieczeństwa dzieci w Internecie [An Analysis of Parents' Competences in Children Safety in the Internet]. Kultura - Społeczeństwo - Edukacja nr 1, 2012, Poznań 2012, pp. 141-155, Adam Mickiewicz University Press. ISBN 978-83-232-2470-9

In the last three years there had been conducted several researches in Poland, which were related to competences and consciousness of parents in the field of children safety in the Internet, including the research conducted in 2010 in all European Union countries (the EU Kids Online research). In this paper the author focuses mainly on the comparison and synthesis of the result of these researches on safety of children in the Internet and parent's competences in that matter as well on presentation of conclusions drawn from these results. The paper also presents briefly types and classification of Internet threats, as well the analysis of activities and competences of children in the Web.
\end{abstract}

\section{Wprowadzenie}

Wiek inicjacji internetowej obniża się do wieku przedszkolnego, w którym to dziecko pozostaje poza sferą formalnej edukacji informacyjnej, a rodzic jest wówczas zazwyczaj jedynym podmiotem mogącym bezpiecznie je wdrażać w świat Internetu. W wieku wczesnoszkolnym do podmiotów tych obligatoryjnie dołączają nauczyciele zajęć komputerowych, a w późniejszych etapach technologii informacyjnych oraz informatyki, a także, $z$ uwagi na interdyscyplinarny charakter edukacji informacyjnej w systemie szkolnictwa formalnego, nauczyciele wszystkich przedmiotów. Rola rodzica jako protektora przed zagrożeniami z Sieci i przewodnika po bezpiecznym użytkowaniu Internetu jest jednak nadal najbardziej znacząca, gdyż to właśnie dom rodzinny jest miejscem, w którym dzieci najczęściej obcują ze światem wirtualnym. Współczesne dzieci i młodzież w Polsce są jednostkami od urodzenia osadzonymi w świecie technologii informacyjnych, a ich rodzice w ten 
świat wchodzili w wieku kilku, kilkunastu lat, gdy i również ów technologiczny świat zaczynał raczkować, a upowszechnienie Internetu miało miejsce dopiero na przełomie końca lat dziewięćdziesiątych XX wieku i na początku XXI wieku. Przygotowanie dziecka i młodego człowieka do funkcjonowania w świecie wirtualnym to współczesne wyzwania wychowawcze i edukacyjne. Istotnym podmiotem tego procesu jest rodzic. Wiedza i kompetencje informacyjne współczesnego rodzica dziecka niepełnoletniego są zazwyczaj pozyskane na drodze samokształcenia lub samouctwa. Jego poziom jest bardzo zróżnicowany a, jak wynika z badań UE Kids Online (Sonck, Livingstone, Kuiper, de Haan, 2011), jednym z czynników różnicujących kompetencje informatyczne jest status socjo-ekonomiczny. Pojawia się zatem pytanie: jakie kompetencje mają rodzice w zakresie zagrożeń wynikających z korzystania $\mathrm{z}$ Internetu i przeciwdziałania im oraz edukacji swoich dzieci w sferze bezpieczeństwa w Sieci? Z punktu widzenia efektywności działań rodzica jako edukatora i wychowawcy istotny jest także poziom świadomość rodziców dotyczący rodzajów działalności w Internecie oraz zagrożeń, z jakimi spotkali się ich podopieczni. Rozbieżności w tej kwestii mogą powodować prowadzenie przez rodziców niewłaściwie skoncentrowanych działań profilaktycznych i edukacyjno-wychowawczych wobec dzieci oraz brak rozwoju własnych kompetencji w zakresie zagrożeń internetowych.

\section{Rodzaje zagrożeń internetowych}

Nowoczesne technologie informacyjne „[... mogą uruchamiać lub hamować procesy poznawcze oraz nadawać im charakter innowacyjny i twórczy, ale także niekiedy zachowawczy i odtwórczy, a nawet wręcz destrukcyjny i burzący" (Wenta, 2004: 532). Funkcjonowanie w wirtualnym świecie, jak w każdym innym, stawia człowieka zarówno w obliczu profitów, jak i zagrożeń. Do zagrożeń związanych z korzystaniem z Internetu zalicza się:

- kontakty z przedstawicielami niebezpiecznych środowisk społecznych, takich jak sekty, ruchy neonazistowskie itp., osobami nakłaniającymi do samobójstw itp.;

- uwodzenie dzieci online (ang. grooming);

- kontakty z niebezpiecznymi treściami (ang. harmful content) i materiałami mogącymi mieć szkodliwy wpływ na rozwój i psychikę dziecka. „Jedna z przyjętych typologii problemu wyróżnia treści: prezentujące przemoc, pornografię, propagujące rasizm i ksenofobię, nawołujące do popełnienia przestępstwa, promujące faszystowski lub inny totalitarny ustrój państwa, zachęcające do prostytucji, używania narkotyków czy hazardu, zawierające elementy psychomanipulacji (np. namawiające do przystąpienia do sekty)" (Raport: Bezpieczeństwo dzieci..., 2011: 14); 
- cyberprzemoc (cyberagresja, przemoc rówieśnicza): ogólnie przemoc przy użyciu technologii informacyjnych i komunikacyjnych; niektóre definicje zawężają ją do przemocy rówieśniczej. To tej kategorii zalicza się: nękanie, straszenie, szantażowanie przy wykorzystaniu Sieci, publikowanie lub rozsyłanie ośmieszających, kompromitujących treści (informacji, zdjęć, filmów), kradzież tożsamości (podszywanie się pod kogoś bez jego zgody);

- cyberprzestępczość: „przestępstwa związane z komputerem i Internetem i ukierunkowanych na systemy i dane komputerowe, takich jak włamania do systemów komputerowych (hacking, cracking), nielegalne kopiowanie i rozpowszechnianie programów komputerowych (piractwo), nieuprawnione niszczenie danych komputerowych itp. Należy mieć na uwadze, że dzieci jako użytkownicy Internetu i komputera padają ofiarami takich przestępstw, ale również często są ich sprawcami" (Raport: Bezpieczeństwo dzieci..., 2011: s. 17);

- przestępstwa tradycyjne: takie jak kradzieże, oszustwa, wyłudzenia itp.;

- zespół uzależnienia od Internetu (patologiczne używanie Internetu - PUI): syndrom uzależnienia się od przebywania w Internecie'. Wyróżnia się specyficzny i niespecyficzny typ patologicznego używania Internetu. „Specyficzny typ [...] obejmuje osoby, które przejawiają zależność do konkretnych funkcji Internetu, [...] związany jest tylko $\mathrm{z}$ jednym aspektem Internetu i istnieje całkowicie niezależnie od jego różnorodnych funkcji. Niespecyficzny typ PUI skutkuje wielowymiarowym nadużywaniem Internetu, [...] wydaje się być związany ze społecznym aspektem Internetu" (Davis, 2009: 374).

Skala poszczególnych zagrożeń jest różna, w niektórych przypadkach niemożliwa do określenia, a w niektórych można jedynie dokonywać prób jej estymacji. Zjawiska te jednak nie na należą do marginalnych i, jak wynika z badań, zdecydowana większość rodziców ma świadomość niebezpiecznego potencjału tkwiącego w Internecie, ale z drugiej strony nie potrafi wskazać konkretnych zagrożeń, ponadto znaczna część rodziców uważa, że problem ten nie dotyczy ich dzieci. W dzisiejszych czasach, w których dzieci narażone są na zagrożenia $\mathrm{z}$ wielu stron, rodzice najczęściej są o tych zagrożeniach alarmowani i trudno sądzić, by nie mieli świadomości ich istnienia, jednak w większości przypadków zdecydowanie brakuje koncentracji na sposobach zapobiegania zagrożeniom i radzenia sobie z nimi w przypadku ich pojawiania się.

W badaniu EU Kids Online przyjęto klasyfikację typów zagrożeń przedstawioną w tabeli 1.

\footnotetext{
${ }^{1}$ Brak jednolitej definicji tego zjawiska oraz kryteriów diagnostycznych.
} 
Tabela 1. Klasyfikacja zagrożeń internetowych

\begin{tabular}{|c|c|c|c|}
\hline Typ zagrożenia & $\begin{array}{c}\text { Ekspozycja na } \\
\text { niewłaściwe treści } \\
\text { w Internecie } \\
\text { (zawartość) }\end{array}$ & $\begin{array}{c}\text { Doświadczenia } \\
\text { użytkownika } \\
\text { w wyniku kontaktów } \\
\text { z innymi osobami } \\
\text { online (kontakt) }\end{array}$ & $\begin{array}{c}\text { Doświadczenia } \\
\text { i własne zachowania } \\
\text { użytkownika w Sieci } \\
\text { (zachowanie) }\end{array}$ \\
\hline $\begin{array}{l}\text { Agresywne wzorce } \\
\text { zachowania }\end{array}$ & $\begin{array}{l}\text { Przemoc/ } \\
\text { okrucieństwo/ } \\
\text { drastyczne sceny }\end{array}$ & $\begin{array}{l}\text { Doznawanie } \\
\text { dręczenia/znęcania } \\
\text { się/napastliwości } \\
\text { ze strony innych }\end{array}$ & $\begin{array}{l}\text { Dręczenie/ } \\
\text { napastliwość } \\
\text { (cyberagresja) }\end{array}$ \\
\hline $\begin{array}{l}\text { Niewłaściwe wzorce } \\
\text { zachowania w sferze } \\
\text { seksualnej }\end{array}$ & Pornografia & $\begin{array}{l}\text { Doświadczenie bycia } \\
\text { uwiedzionym }\end{array}$ & Seksting \\
\hline $\begin{array}{l}\text { Wadliwy system } \\
\text { wartości }\end{array}$ & Rasizm/nienawiść & $\begin{array}{l}\text { Perswazja } \\
\text { ideologiczna }\end{array}$ & Samouszkodzenia \\
\hline $\begin{array}{l}\text { Wadliwe wzorce } \\
\text { zachowań } \\
\text { konsumenckich }\end{array}$ & Marketing, perswazja & $\begin{array}{l}\text { Naruszanie } \\
\text { prywatności/danych }\end{array}$ & $\begin{array}{l}\text { Ściąganie, filmów, } \\
\text { klipów, dokumentów, } \\
\text { zachowania } \\
\text { hakerskie, hazard } \\
\text { online }\end{array}$ \\
\hline
\end{tabular}

Źródło: Kirwil, 2011: 17

\section{Analiza aktywności i kompetencji dzieci w Internecie}

Analizy aktywności dzieci w Sieci oraz kompetencji ich i ich rodziców w zakresie bezpieczeństwa w Internecie dokonano na podstawie następujących badań i raportów:

- EU Kids Online²: badania kwestionariuszowe „Dzieci z Unii Europejskiej w Sieci” zrealizowane w 2010 roku zgodnie ze standardami badawczymi przez naukowców w 25 krajach Unii Europejskiej, sfinansowane przez Komisję Europejską w ramach projektu Safer Internet, przeprowadzone na próbie kwotowej 25142 dzieci w wieku 9-16 lat korzystających z Internetu oraz jednym z rodziców każdego dziecka, oraz raport „Polskie dzieci w Internecie. Zagrożenia i bezpieczeństwo - część 2” (Kirwil, 2011). W Polsce badaniem objęto 1034 dzieci wraz z jednym z rodziców z populacji liczącej 3385563 (estymator: 97\%³, populacja: 3490 271) dzieci w wieku 9-16 lat korzystających z Internetu;

${ }^{2}$ Wszelkie informacje dotyczące badania i raporty z badań dostępne na www.eukidsonline.net (dostęp 11.09.2012).

3 Źródło: Technical raport - EU Kids Online II, www.eukidsonline.net (dostęp 20.03.2011). 
- „Rodzice wobec zagrożeń dzieci w Internecie”4: badanie kwestionariuszowe zrealizowane w Polsce w 2008 r. przez TNS OBOP dla Fundacji Dzieci Niczyje, przeprowadzone na próbie reprezentatywnej 500 rodziców dzieci w wieku 7-17 lat korzystających w domu $\mathrm{z}$ Internetu ${ }^{5}$;

- „Dzieci online w oczach rodziców”: badanie kwestionariuszowe zrealizowane w Polsce w 2008 r. przez firmę Gemius S.A. we współpracy Fundacji Dzieci Niczyje, przeprowadzone na próbie 1235 osób posiadających dziecko w wieku 5-15 lat korzystające $z$ Internetu.

Średni wiek pierwszego logowania się do Internetu według badania EU Kids Online wynosi 9 lat, należy jednak pamiętać, że o kwestię tę pytano w badaniu dzieci w wieku 9-16 lat, a odnotowuje się malejącą tendencję wieku pierwszego logowania się do Sieci. Uwzględniając ową tendencję w odniesieniu do dzieci młodszych, należy prognostycznie przyjmować ten wiek jako niższy. Z badania „Rodzice wobec zagrożeń dzieci w Internecie” wynika, iż aż w 41\% dzieci korzystało samodzielnie z Internetu przed ukończeniem 9. roku życia, a 14\% przed ukończeniem 6. roku życia. W badaniu „Dzieci online w oczach rodziców” aż 16\% rodziców odpowiedziało, że ich dziecko miało kontakt (nie oznacza to, że samodzielnie korzystało) z Internetem w wieku 4 lata lub młodszym.

Dzieci korzystają z Internetu bardzo często i aktywność ta wzrasta wraz z wiekiem. Wykres 1 przedstawia częstotliwość korzystania z Internetu przez dzieci w wieku 9-16 lat.

\section{Częstotliwość korzystania z Internetu przez dzieci w wieku 9-16 lat}

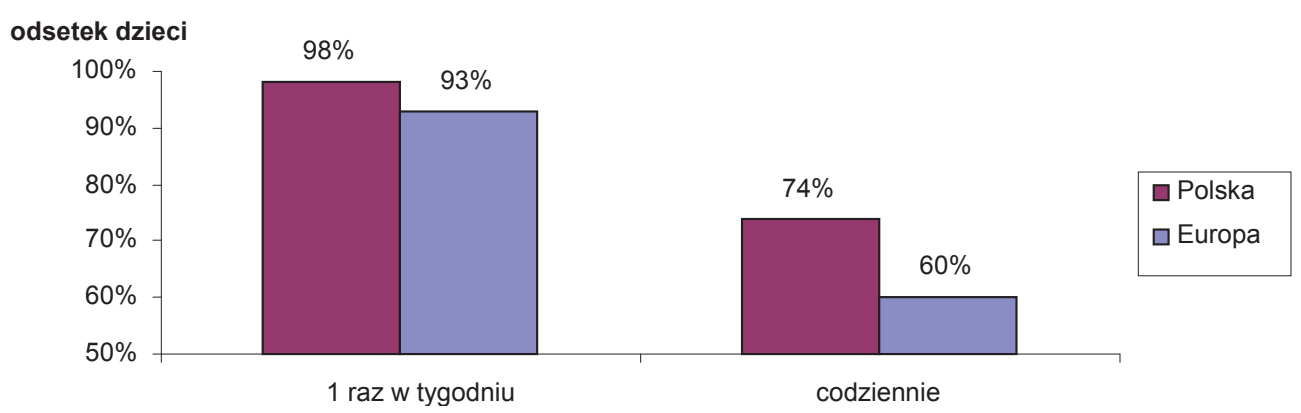

Wykres 1. Częstotliwość korzystania z Internetu dzieci w wieku 9-16 lat

Źródło: opracowanie własne na podstawie Kirwil, 2011

\footnotetext{
${ }^{4}$ Raport dostępny na stronie http://www.dzieckowsieci.pl (dostęp 20.03.2011).

5 Raport z badania: Ł. Wojtasik, Rodzice wobec zagrożeń dzieci w Internecie, www.dzieckokrzywdzone.pl (dostęp 20.03.2011).

${ }^{6}$ Raport dostępny na stronie http://www.dzieckowsieci.pl (dostęp 20.03.2011).
} 
Dzieci w Polsce korzystają z Internetu częściej niż dzieci w innych krajach europejskich. Niemal wszystkie korzystają z Internetu przynajmniej raz w tygodniu, a blisko $3 / 4$ korzysta codziennie. Zatem znaczna większość dzieci niemal codziennie jest potencjalnie narażona na konfrontację z zagrożeniami wynikającymi z używania Internetu. Ponadto „[...] polskie dzieci częściej łączą się z Internetem poza możliwościami kontroli rodzicielskiej: więcej z nich (52\%) niż średnio w Europie (35\%) łączy się z Internetem z komputera osobistego tylko do własnej dyspozycji (prywatnego)" (Kirwil, 2011: 10). W ten sposób wyeliminowany zostaje czynnik stałej, bezpośredniej kontroli rodzicielskiej i wzrasta ryzyko doświadczania zagrożeń, zatem jeszcze większej wagi nabiera poziom świadomości zagrożeń internetowych u dzieci, maksymalizacja eliminacji tych zagrożeń oraz umiejętności radzenia sobie z nimi przez dzieci. Wzrasta konieczność zwiększenia działań edukacyjnych dzieci związanych z bezpieczeństwem w Sieci, a także edukacji rodziców, w obrębie której należy także uświadamiać konieczność monitorowania działalności dziecka w świecie wirtualnym. W obliczu takiej sytuacji bardzo ważnym czynnikiem mającym wpływ na bezpieczeństwo dzieci jest także wsparcie rodzicielskie oraz waga zaufania dziecka do rodzica i włączanie go przez dziecko w proces pomocy w sytuacjach kryzysowych lub zagrożenia, a paradoksalnie odizolowane przebywania dzieci w Sieci wpływa odwrotnie proporcjonalnie do pogłębiania więzi rodzinnych, powoduje oddalenie się dzieci od rodziców, co implikuje niechęcią włączania przez dziecko rodziców do swojego życia.

Z badania „Dziecko w Sieci” przeprowadzonego przez Gemius S.A. i Fundację Dzieci Niczyje w styczniu 2006 roku na próbie 1779 dzieci w wieku 12-17 lat wynika, że 92\% z nich korzysta z komunikatorów, 91\% ze stron internetowych, 85\% z poczty elektronicznej, a $51 \%$ z gier online. Natomiast z badania przeprowadzonego przez Megapanel PBI/Gemius zrealizowanego w listopadzie 2007 roku na grupie ponad 17 tysięcy internautów w wieku 7-14 lat wynika, że „70\% internautów w tym wieku korzysta $\mathrm{z}$ możliwości grania online i jest to grupa, która gra w gry online najczęściej. Druga w kolejności jest młodzież w wieku 15-24 lata (55\%). Wbrew stereotypom dziewczynki poświęcają na gry online nieco więcej czasu niż chłopcy" (Raport: Bezpieczeństwo dzieci..., 2011: 5). Ogólnie dziewczynki spędzają więcej czasu w Internecie niż chłopcy. Konta na portalach społecznościowych ma $71 \%$ polskich dzieci w wieku 9-16 lat i jest to o $12 \%$ więcej w porównaniu do przeciętnej w Europie ${ }^{7}$.

Większość dzieci i młodzieży w Polsce intensywnie korzysta prawie ze wszystkich oferowanych usług internetowych, zatem znajduje się także w grupie znacznego ryzyka związanego $\mathrm{z}$ konfrontacją z zagrożeniami wynikającymi z bytnością $\mathrm{w}$ świecie wirtualnym. W tej sytuacji znaczenia nabiera analiza kompetencji dzieci i ich ro-

\footnotetext{
${ }^{7}$ Na podstawie badania EU Kids Online, www.eukidsonline.pl (dostęp 20.03.2011).
} 
dziców z zakresu bezpieczeństwa w Internecie, która prowadzić może do wytypowania obszarów najsłabszych w tym zakresie oraz tworzenia programów edukacyjnych i profilaktycznych nie rozmijających się z rzeczywistymi zapotrzebowaniami.

\section{Analiza kompetencji i świadomości rodziców w zakresie bezpieczeństwa i zagrożeń wynikających z korzystania z Internetu}

Prawie wszyscy $\left(98 \%^{8}\right)$ rodzice twierdzą, że to głównie oni ponoszą odpowiedzialność za bezpieczeństwo swoich dzieci w Internecie. A z drugiej strony aż 70\% rodziców twierdzi, że ich umiejętności korzystania z Internetu są na takim samym (19\%) lub niższym poziomie niż umiejętności ich dzieci. Wobec wysokiego poczucia odpowiedzialności rodziców w zakresie bezpieczeństwa dzieci w Sieci i niskich umiejętności korzystania $\mathrm{z}$ Internetu istotne staje się dokładne określenie zakresu kompetencji w tej sferze oraz świadomość funkcjonowania ich dzieci w Sieci i w oparciu o nie stworzenia działań wspierających rodziców w roli głównego protektora dziecka w Sieci.

Znaczna część $\left(87 \%^{9}\right)$ rodziców ma świadomość występowania zagrożeń wynikających z korzystania z Internetu, ale ich kompetencje w zakresie przeciwdziałania nie kształtują się na wystarczającym poziomie. Do najpoważniejszych zagrożeń wynikających z korzystania $\mathrm{z}$ Internetu rodzice zaliczają ${ }^{10}$ :

- kontakty z treściami pornograficznymi i przemocą: $67 \%$,

- publikowanie lub przesyłanie przez dziecko prywatnych danych: $60 \%$,

- nawiązywanie kontaktów i znajomości z obcymi w Internecie: 51\%,

- spotykanie się z osobami poznanymi w Internecie: $22 \%$,

- publikowanie lub przesyłanie przez dziecko prywatnych filmów: 19\%,

- uzależnienie od Internetu: 16\%,

- publikowanie w Internecie przez rówieśników zdjęć i filmów z udziałem dziecka wbrew jego woli: 15\%,

- przemoc werbalna w Internecie ze strony rówieśników: 14\%,

- kontakt $\mathrm{z}$ nieprawdziwymi treściami: $8 \%$,

- oszustwa związane z zakupami w Internecie: $6 \%$,

- obniżenie umiejętności komunikowania się z innymi w świecie rzeczywistym: $4 \%$,

- nielegalne ściąganie/przesyłanie programów, filmów, dokumentów: 3\%.

\footnotetext{
${ }^{8}$ Na podstawie badania „Rodzice wobec zagrożeń dzieci w Internecie”.

${ }^{9}$ Na podstawie badania internetowego przeprowadzonego pod koniec 2010 roku przez Instytut GFK Polonia na zlecenie Linksys by Cisco.

${ }^{10}$ Na podstawie badania „Rodzice wobec zagrożeń dzieci w Internecie”. Wybór maksymalnie trzech z przedstawionych zagrożeń.
} 
Zaskakujący jest fakt, że jako większe zagrożenie postrzegany jest kontakt $\mathrm{z}$ obcymi w świecie wirtualnym niż spotkania w rzeczywistości $\mathrm{z}$ osobami poznanymi w Sieci. Ponad połowa rodziców jako jedno z trzech najpoważniejszych zagrożeń wskazała nawiązywanie kontaktów i znajomości z obcymi w Internecie, a jedynie co piąty badany wskazał spotkanie się z osobami z Internetu. Niepokój budzi także fakt, iż zaledwie 16\% rodziców jako jedno z najważniejszych zagrożeń uznało uzależnienie od Internetu. Również grupa zagrożeń związanych z cyberprzemocą była bardzo rzadko wskazywana jako jedno z trzech największych zagrożeń. Powstaje pytanie o przyczyny takiej sytuacji: czy jest to spowodowane tym, iż rodzice uważają, że takie zagrożenia są zjawiskami, które nie są najważniejszymi zagrożeniami, mającymi najgorsze konsekwencje, czy raczej są zjawiskami o stosunkowo rzadkim występowaniu i występuje według nich nikłe lub żadne ryzyko pojawienia się tego zagrożenia w kontekście ich własnego dziecka, czy może wierzą w zaradność dziecka wobec takich zagrożeń? Ustalenie przyczyn tego zjawiska jest istotne z punktu widzenia typowania działań profilaktycznych i edukacyjnych.

Istotne jest dokonanie konfrontacji między świadomością rodziców odnośnie zagrożeń, z jakimi spotkało się ich dziecko w Internecie, a ich rzeczywistym występowaniem.

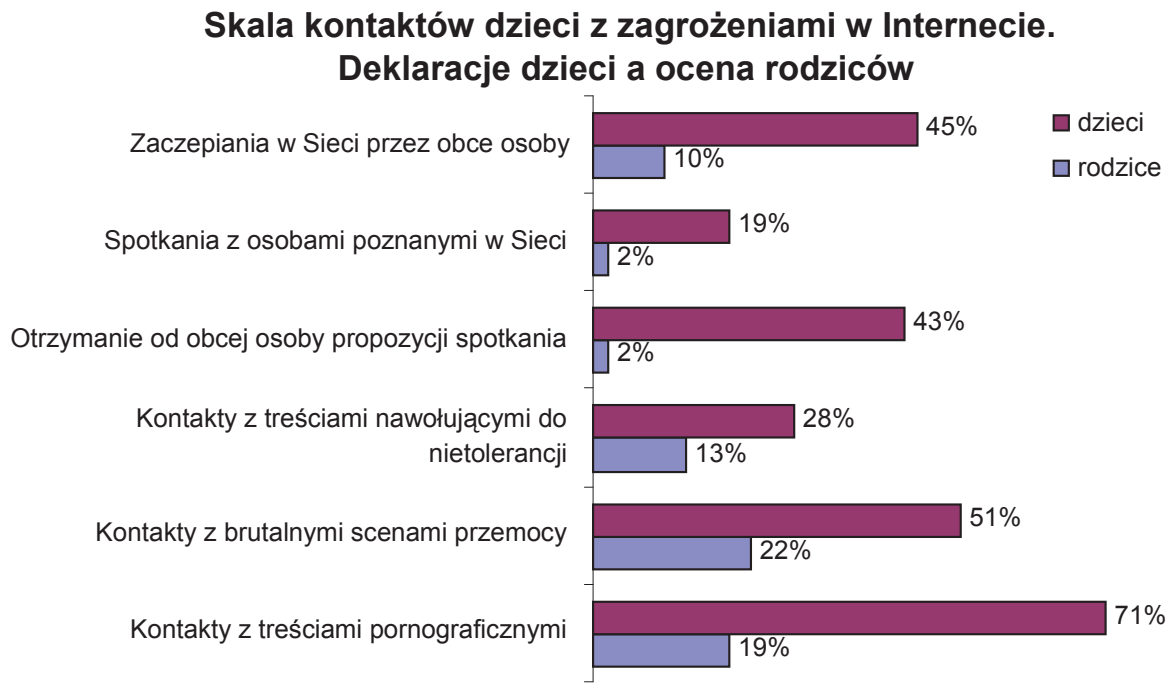

Wykres 2. Skala kontaktów dzieci z zagrożeniami w Internecie 
Analiza wyników badań w zakresie kontaktów dzieci z zagrożeniami w Internecie jest oczywiście, po pierwsze, zaskakująca w kwestii znacznej rozbieżności pomiędzy oceną dzieci a oceną ich rodziców, a, po drugie, bardzo znamienna, wskazująca na poziom głębokości i częstości interakcji pomiędzy dziećmi i rodzicami. Wyobrażenia rodziców odnośnie własnych dzieci nie są spójne. Dzieci pozostawione niejednokrotnie same sobie, kiedyś wychowywane przez „podwórko”, dzisiaj skazane są na samotną wędrówkę w świecie wirtualnym, w którym rodzice nie widzą albo nie chcą zauważyć rzeczywistych zagrożeń. Przeciętny rodzic, obawiający się niebezpieczeństw ze strony świata realnego, zdecydowanie bardziej bezpiecznie czuje się, gdy dziecko nie opuszcza domu rodzinnego pod nieobecność dorosłych, a zapomina czasami o tym, że zostawiając dziecko z włączonym komputerem $\mathrm{z}$ dostępem do Internetu, zostawia je $\mathrm{z}$ otwartymi drzwiami dla przemocy $\mathrm{i}$ innych zagrożeń. Drzwiami, w których dzieci od progu wołają, że są same, samotne i bezbronne, a z zaproszenia korzystają osoby, które tych potrzeb nie zaspokoją.

\section{Doświadczenia przez dzieci poszczególnych typów zagrożeń}

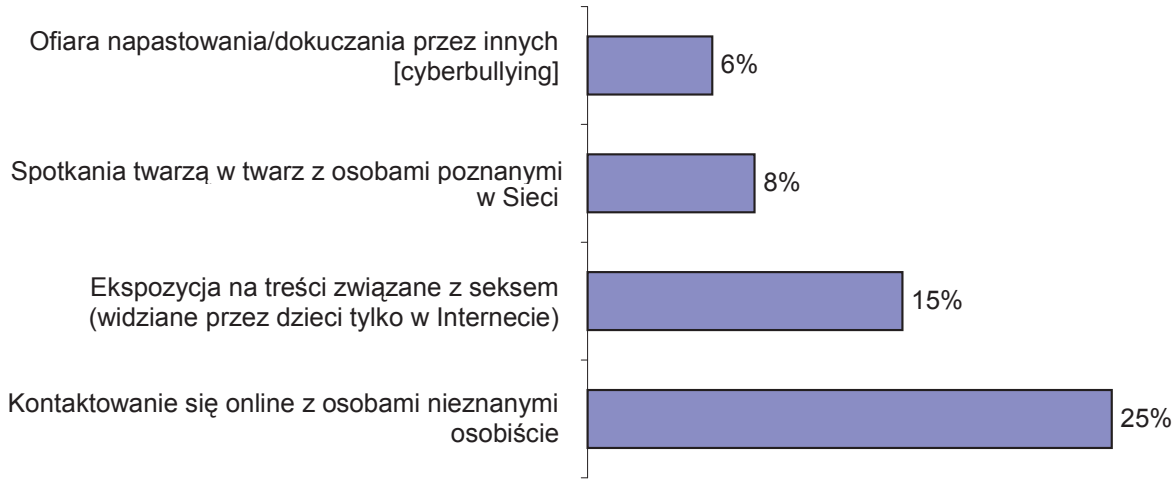

Wykres 3. Doświadczenia przez dzieci poszczególnych typów zagrożeń

Należy zwrócić uwagę na to, iż badania dzieci i rodziców były przeprowadzone w różnych latach i dotyczyły dzieci w innym wieku. Z badanie EU Kids Online wynika, że odsetek dzieci, które deklarują, że nie doświadczyły żadnego zagrożenia w Internecie, maleje $\mathrm{z}$ wiekiem, zatem im starsze dziecko, tym jest bardziej narażone na niebezpieczeństwa wynikające z korzystania z Internetu. Potwierdzają to także wyniki przedstawione na wykresach 2. i 3. Wprawdzie wskaźników struktury 
odpowiedzi dzieci i rodziców nie powinno się porównywać bezpośrednio na podstawie tych danych, jednakże różnica jest bardzo duża i można przyjąć hipotezę, że ocena skali zagrożeń według rodziców jest istotnie niższa niż skala zagrożeń, na które faktycznie dzieci zostały narażone. Fakt ten może być efektem rozbieżności między kompetencjami informacyjnymi rodziców i dzieci, ale na pewno potwierdza niski poziom dialogu i więzi między tymi pokoleniami. Warte jest także zweryfikowanie, czy rodzice wskazujący na fakt, iż ich dziecko zostało narażone na konkretne zagrożenie, są grupą rodziców, których dzieci zadeklarowały, że dane zagrożenie miało miejsce, czy raczej jest to inna grupa rodziców, która swoją ocenę występowania zagrożenia wystawiła na zasadzie przypuszczenia, a nie znajomości faktów. Powstaje konieczność zapełnienia nierozpoznanych obszarów badawczych oraz przeprowadzenia badań bardziej rzetelnych i jednorodnych, mających na celu bardziej dokładne zdiagnozowanie powstałej sytuacji, gdyż konieczne jest stworzenie efektywnych działań profilaktycznych i edukacyjnych skierowanych do rodziców.

Znaczna część rodziców $\left(90 \%{ }^{11}\right)$ deklaruje, iż podejmuje z dziećmi rozmowy na tematy związane z bezpieczeństwem w Internecie. „Najczęściej podejmują oni temat ochrony prywatnych danych (85\%), kontaktów z obcymi w Sieci $(83 \%)$ oraz kontaktów z niebezpiecznymi treściami (77\%). Dalsze tematy to: uzależnienie od Internetu (68\%), spotkania z osobami poznanymi w Sieci (67\%) oraz piractwo (55\%). Stosunkowo rzadko rodzice rozmawiają z dziećmi o cyberprzemocy - zarówno o przemocy werbalnej (54\%), jak i o publikowaniu zdjęć lub filmów bez zgody zainteresowanego (53\%)" (Wojtasik, 2008: 5). Niwelacja zagrożeń internetowych wymaga poza rozmowami także włączenia czynnika kontroli rodzicielskiej. „Wyróżnia się pięć podstawowych kategorii zabiegów rodzicielskich mających na celu ochronę dziecka przed tymi skutkami: ochronę aktywną, ochronę bierną, restrykcje, wspólne aktywności w Internecie oraz korzystanie $\mathrm{z}$ technologii (specjalnego oprogramowania). Zabiegi te odnoszą się kolejno do:

- rozmów z dzieckiem na temat tego, co robi w Internecie;

- wspólnego korzystania z Internetu lub wspólnej aktywności w Internecie wraz z dzieckiem, np. grania w grę online;

- przebywania w pobliżu dziecka, gdy surfuje ono po Internecie,

- określania zasad, w jaki dziecko może korzystać z Internetu, przy czym najczęściej chodzi o zasady ograniczające czas lub sposób korzystania z Internetu,

- instalowaniu na komputerze dziecka oprogramowania filtrującego lub blokującego dziecku korzystanie z Internetu w wybranych obszarach bądź umożliwiającego wgląd w historię aktywności dziecka w Internecie" (Kirwil, 2011:31).

11 Na podstawie badania „Rodzice wobec zagrożeń dzieci w Internecie”. 


\section{Sposoby ochrony w Internecie stosowane przez rodziców}

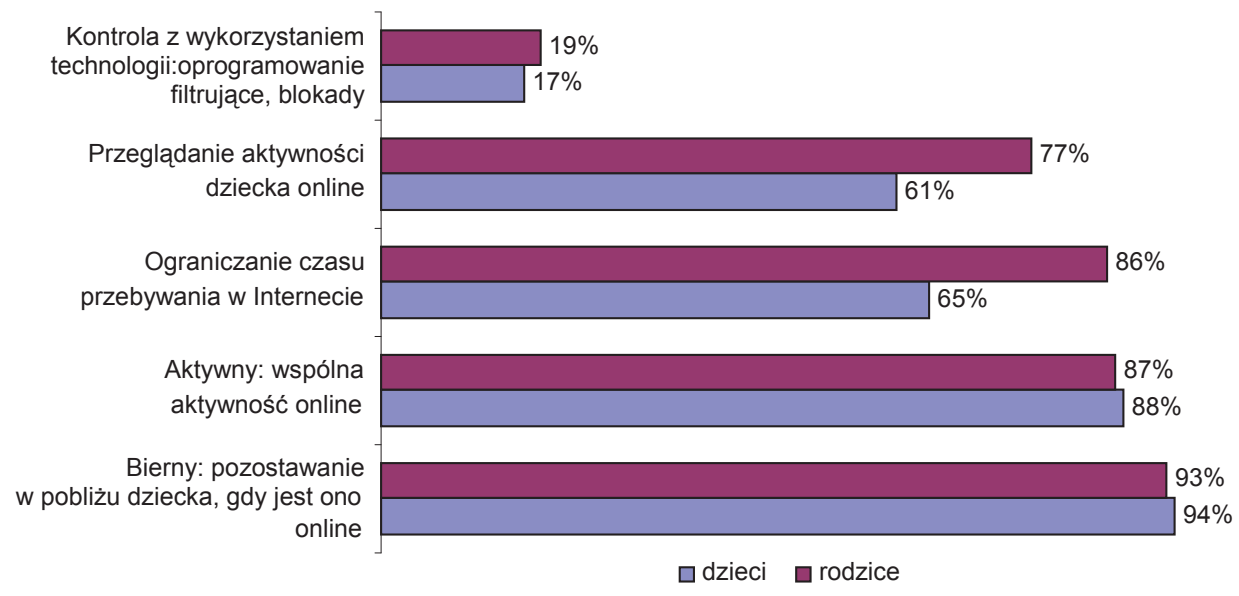

Wykres 4. Sposoby ochrony w Internecie stosowane przez rodziców

Źródło: Opracowanie własne na podstawie wyników z badania EU Kids Online

Największy rozdźwięk między zdaniem rodziców a ich dzieci występuje w obszarze kontroli związanej z ograniczaniem czasu przebywania dzieci w Internecie, gdzie wyniki rodziców mogą być przeszacowane z uwagi na przeświadczanie, że taka kontrola powinna występować lub restrykcja czasowa jest nakładana, ale brakuje konsekwencji w jej przestrzeganiu. Drugą rozbieżność w opiniach dzieci i rodziców obserwuje się w obszarze ochrony związanej z przeglądaniem aktywności dziecka online, która może wynikać z nieświadomości dzieci o stosowaniu takich działań ze strony rodziców. Poza tymi dwoma obszarami występuje zgodność odpowiedzi dzieci i rodziców w zakresie sposobów ochrony rodzicielskiej w Internecie. Stosunkowo rzadko rodzice stosują kontrolę z wykorzystaniem technologii i nie wszystkie dzieci, których ta kontrola dotyczy, mają jej świadomość. W większości rodzice, którzy nie stosują tego typu kontroli, jako powód niezainstalowania oprogramowania kontrolującego funkcjonowanie w Internecie podaje zaufanie do swoich dzieci, a 16\% rodziców nie potrafi w ogóle korzystać z tego typu oprogramowania.

Z badań EU Kids Online (Kirwil, 2011: 35) wynika, że dzieci rodziców, którzy stosują zabiegi mające na celu ochronę dzieci w Sieci, są mniej narażone na niebezpieczeństwa związane z korzystaniem z Internetu. Największe różnice między odsetkiem dzieci, które napotkały przynajmniej jedno zagrożenie i których rodzice stosują zabiegi ochronne lub kontrolujące w porównaniu do niestosujących takowych, obserwuje się dla zabiegów takich jak: wspólne działania w Internecie, rozmowy z dzieckiem na temat tego, co robi w Internecie, przebywanie 
z dzieckiem, gdy działa w Sieci, pomoc w sytuacji, gdy coś zaniepokoiło dziecko oraz wprowadzenie reguł korzystania z Sieci. Z tych samych badań wynika także, że bezpieczeństwo dzieci w Internecie jest także uzależnione od wieku i statusu socjo-ekonomicznego. Dzieci starsze oraz dzieci pochodzące z domów o wyższym statusie socjo-ekonomicznym posiadają wyższe kompetencje w zakresie tego bezpieczeństwa.

\section{Zakończenie}

Wyniki badań wskazują, iż większość (90\%) rodziców rozmawia z dziećmi na tematy związane $z$ bezpieczeństwem i funkcjonowaniem w Sieci, ale jednocześnie ujawniają duże różnice między przeświadczeniem rodziców o skali zagrożeń, jakich doznały ich dzieci, a rzeczywistą skalą, zatem wypowiedzi tych nie można uznać ani za skuteczne, ani za szczere ze strony dzieci. W takiej sytuacji pojawia się także przypuszczenie o zawyżonych wynikach dotyczących frakcji rodziców twierdzących, że rozmawiają z dziećmi o bezpieczeństwie w Internecie, wynikających z fałszowania przez rodziców odpowiedzi rzeczywistych i podawania odpowiedzi bardziej pożądanych. Rodzice są zdania, że dbanie o bezpieczeństwo dzieci w Internecie to głównie ich zadanie, jednocześnie większość z nich przyznaje, że ich kompetencje informatyczno-informacyjne są niższe niż ich dzieci, a także mimo świadomości występowania zagrożeń internetowych nie mają świadomości, że faktycznie narażane są na nie ich własne dzieci. $Z$ uwagi na powyższe, a także na fakt, że zabiegi oraz kontrola rodzicielska przyczyniają się do zmniejszenia ryzyka doświadczania zagrożeń wynikających z korzystania przez dzieci z Internetu, dużego znaczenia nabiera edukacja i profilaktyka rodziców w tym zakresie, zwłaszcza kierowanie tego typu działań do środowisk o niskim statusie socjo-ekonomicznym. Większość kampanii, akcji czy działań związanych z bezpieczeństwem dzieci w Sieci związanych jest z uświadamianiem rodzajów zagrożeń, a nie sposobów przeciwdziałania im i wzrostem kompetencji rodziców w tym zakresie.

Edukacja rodziców w obszarze bezpieczeństwa dzieci w Internecie poza czynnikiem przekazywania wiedzy w omawianym zakresie powinna koncentrować się także na roli i sposobie komunikacji z dziećmi i wzmacnianiu wspólnych więzi. Ma to duże znaczenie w obliczu obserwowanego zjawiska osłabiania się więzi między członkami rodziny. Atomizacja społeczna prowadzi do „[...] uniezależnienia się jednostki od bezpośredniej pomocy innych członków rodziny" (Grabowska, 2004: 104). W tym kontekście efektywność rodzica jako osoby mającej chronić dziecko przed zagrożeniami internetowymi, a nie potrafiącym budować z dzieckiem więzi opartej na wzajemnym zaufaniu i dialogu, będzie znikoma lub żadna. 
Przed przystąpieniem do działań wdrażających edukację rodziców w zakresie zagrożeń dzieci w Sieci należy uzupełnić badania, dokonać diagnozy rzeczywistego stanu kompetencji rodziców w tym zakresie i konfrontacji z kompetencjami dzieci oraz analizy porównawczej między rodzicielską świadomością funkcjonowania własnego dziecka w Internecie a jego faktycznym funkcjonowaniu. Pozwoli to na wdrożenie programów edukacyjnych skierowanych do rodziców adekwatnych do rzeczywistych potrzeb a nie tylko polegających na uświadamianiu samych zagrożeń i przeciwdziałania im skoncentrowanego na ogólnikach informacyjnych i działaniach technicznych.

\section{Literatura}

Davis R.A. (2009). Poznawczo-behawioralny model patologicznego używania Internetu. [W:] Internet a psychologia. Możliwości i zagrożenia. (Red.) W.J. Paluchowski. Warszawa

Grabowska A. (2004). Rodzina wobec przemocy w Internecie. [W:] Wspótczesna technologia informacyjna i edukacja medialna. (Red.) T. Lewowicki, B. Siemieniecki. Toruń

Kirwil, L. (2011). Polskie dzieci w Internecie. Zagrożenia i bezpieczeństwo - część 2. Częściowy raport $z$ badań EU Kids Online II przeprowadzonych wśród dzieci w wieku 9-16 lat i ich rodziców, SWPS - EU Kids Online - PL. Warszawa

Raport: Bezpieczeństwo dzieci korzystajacych $z$ Internetu. www.dzieciwsieci.pl (dostęp 20.03.2011)

Risk and Safety on the Internet. The Perspective of European Children. Livingstone S. at all. www. eukidsonline.net (dostęp 20.03.2011)

Sonck, N., Livingstone, S., Kuiper, E., de Haan, J. (2011). Digital Literacy and Safety Skills. www. eukidsonline.net (dostęp 20.03.2011)

Wenta K. (2004). Samouctwo informacyjne jako metoda studiowania w świecie ponowoczesnym. [W:] Wspótczesna technologia informacyjna i edukacja medialna. (Red.) T. Lewowicki, B. Siemieniecki. Toruń

Wojtasik Ł. (2008). Rodzice wobec zagrożeń dzieci w Internecie. www.dzieckokrzywdzone.pl (dostęp 20.03.2011)

Technical report - EU Kids Online II. www.eukidsonline.net (dostęp 20.03.2011)

www.eukidsonline.net (dostęp 20.03.2011)

\section{An Analysis of Parents' Competences in Children Safety in the Internet}

\section{Summary}

The age when children start using the Internet has decreased to the pre-school period. These children are outside the formal system of education so parents are responsible for introducing them to safe use of the Internet. The role of parental supervision of the Internet is crucial because the family home is the place where children have access to the Internet. The IT skills of 
the contemporary parents of young children are gained through self-study. Their level is diverse and the EU Kids Online study shows that socioeconomic status is one of the discriminatory factors that influences IT abilities. Hence the question arises about what level of competence the parents have within the scope of the Internet's dangers and how do they prevent such dangers? How are the children taught to use the Internet safely?

There are advantages and disadvantages of being a user of the virtual world. The threats of Internet use include: grooming, harmful content, cyber-violence, cyber-crime, conventional crimes and Internet Addiction Disorder. Children are exposed to many threats today so parents are being alerted about them. It is hard to believe that parents are not conscious of these threats but in most cases there is a gap in the preventive and problem-solving methods.

The analysis of parents' competence in children safety with the Internet was based on the following studies: EU Kids Online, Rodzice wobec zagrożeń dzieci w Internecie TNS OBOP, Dzieci online w oczach rodziców.

According to the EU Kids Online study the average age of the first log on to the Internet is 9 years old. The age of the first Internet log on could decrease especially when we notice that in this study, children between the age 9-16 were interviewed. Children use the Internet more frequently in Poland than their peers in Europe. Almost all Polish children use the Internet at least once a week and $75 \%$ use it everyday. Thus most children are being exposed to the threats of Internet use almost every day.

There is a need to increase the educational activities among children about safety on the Net and also to educate parents about the necessity of supervising their children's activities in the virtual world.

According to the study Dziecko $w$ Sieci $71 \%$ of Polish children between the ages of 9-16 have an account on social networks which is about $12 \%$ more than the average in Europe. Most children and youth intensively use almost all available Internet services in Poland. Thus they are at risk of being exposed to the threats of the virtual world.

Almost all parents (98\%) admit that they are responsible for the safety of their children on the Internet. On the other hand as much as $70 \%$ of parents claim that their Internet skills are at the same level as their children's (19\%) or even lower.

Over half of the parents indicated striking up friendships with strangers on the Internet as a one of the most serious threats and only every fifth of the interviewed indicated meeting people from the Internet in person. The alarming fact is that only $16 \%$ of parents regard Internet addiction as one of the most important dangers. Cyber-violence was also indicated very rarely by parents as one of the three most dangerous threats.

Parents often think that it is better to leave their children home alone with free Internet access than to allow them to go out. They forget that unattended Internet use frequently means exposing their children to all its threats.

The EU Kids Online study shows that the proportion of the number of children who admit that they did not experience any harm on the Internet decreases with age, thus the older the child, the more exposed it is to Internet threats.

There is a necessity to carry out more profound research and to do more reliable studies which would diagnose the details of the resultant situation because there is a need to create some effective preventive and educational actions aimed at the parents. A significant number of parents $(90 \%)$ declare that they discuss Internet safety issues with their children. Parental supervision combined with conversations could eliminate Internet threats. One can distinguish five basic parental endeavours aiming to protect a child against the mentioned results: active 
protection, passive protection, restrictions, collective activities on the Internet and using technology (i.e. special software). Parents hardly ever use technology to supervise their children and not all of the children know they are being supervised.

The EU Kids Online study shows that children whose parents use varied means to protect them on the Net are less exposed to the threats of the Internet. Children with a higher socioeconomic status as well as older children have a higher level of competence concerning safety on the Internet. 
